\title{
Expression of Peroxisome Proliferator-Activated Receptor Gamma in Salivary Duct Carcinoma: Immunohistochemical Analysis of 15 Cases
}

Perkins Mukunyadzi, M.D., Lingbao Ai, M.D., Didier Portilla, M.D., E. Leon Barnes, M.D., Chun-Yang Fan, M.D., Ph.D.

Departments of Pathology and Nephrology, University of Arkansas for Medical Sciences (PM, AL, DP, CYF), Little Rock, Arkansas; and Pittsburgh University Medical Center (ELB), Pittsburgh, Pennsylvania

Salivary duct carcinoma is a rare but highly aggressive tumor of the salivary glands that has poor prognosis. There is no effective cure for this tumor. Peroxisome proliferator-activated receptor gamma $(\operatorname{PPAR} \gamma)$ is a member of the nuclear receptor family with diverse biological functions that include mediation of adipocyte differentiation, regulation of the monocyte-macrophage anti-inflammatory activity, and inhibition of tumor cell proliferation. Natural (prostaglandin $\mathrm{J}_{2}, P G-\mathrm{J}_{2}$ ) and synthetic (thiazolinediones) PPAR $\gamma$ ligands with anti-proliferative agonist activity have been identified. The expression of PPAR $\gamma$ has been demonstrated in human colorectal, pancreas, breast, and prostate cancers but has never been explored in salivary duct carcinoma. The aim of our study was to investigate the expression patterns of PPAR $\gamma$ in salivary duct carcinoma, a finding that may provide a mechanism for treating patients with this highly aggressive tumor. Archival formalin-fixed tissues from 15 salivary duct carcinoma cases were analyzed for PPAR $\gamma$ expression by an immunohistochemical staining method using a monoclonal antibody against the PPAR $\gamma$. The tissue sections were subjected to antigen retrieval by a steam heat method. All the cases of salivary duct carcinoma originated from the parotid gland. Immunohistochemistry analyses showed positive expression of PPAR $\gamma$ in $12(80 \%)$ cases, whereas $3(20 \%)$ were negative. Of the positive cases, 9 (75\%), 2 (17\%) and 1 (8\%) showed strong, moderate, and weak staining, respectively. All staining was cytoplasmic. Nuclear staining was not ob-

Copyright () 2003 by The United States and Canadian Academy of Pathology, Inc.

VOL. 16, NO. 12, P. 1218, 2003 Printed in the U.S.A.

Date of acceptance: August 15, 2003.

Address reprint requests to: Perkins Mukunyadzi, M.D., Department of Pathology, University of Arkansas for Medical Sciences, 4301 W Markham Street, Little Rock, AR 72205; fax: 501-603-1479; e-mail: mukunyadziperkins@

uams.edu.

DOI: 10.1097/01.MP.0000096042.70559.7E served. We conclude that PPAR $\gamma$ is frequently $(80 \%)$ expressed in salivary duct carcinoma, often at high levels, and is topographically located in the cytoplasm. The high-level expression of PPAR $\gamma$ may provide a potential molecular target for the treatment of salivary duct carcinoma using agonist ligands.

KEY WORDS: Expression, Immunohistochemistry, Peroxisome proliferator-activated receptor, Salivary duct carcinoma, Treatment.

Mod Pathol 2003;16(12):1218-1223

Salivary duct carcinoma, first described by Kleinsasser et al. (1) in 1968, is a rare tumor of the salivary glands that was officially recognized by the World Health Organization in 1991 as a distinct clinicopathologic entity (2). Clinically, salivary duct carcinoma is characterized by its aggressive biologic behavior, and microscopically, it is characterized by resemblance to infiltrating ductal carcinoma of the breast (3). Many patients $(>50 \%)$ with salivary duct carcinoma have lymph node metastases or show tumor extension into adjacent soft tissues at the time of presentation. The current main modality of treatment, surgical excision, has met with limited success, primarily because many tumors are at an advanced stage with early metastasis at the time of presentation and furthermore because the frequency of recurrence is high. An estimated $66 \%$ of patients with salivary duct carcinoma are dead within 4 years of diagnosis despite surgical resection (3). The response rate to radiation treatment is very poor, and currently there is no effective chemotherapy for this tumor. It is therefore imperative for investigators to explore alternative therapy for salivary duct carcinoma.

Recent studies have shown high levels of androgen receptor expression in salivary duct carcinoma, raising the possibility of using hormonal treatment 
in the management of these patients $(4,5)$. Patients with prostate carcinoma, which shows high frequency of androgen receptor expression, have been successfully managed by anti-androgen hormonal treatment (6). However, clinical studies have yet to be carried out in salivary duct carcinoma to evaluate the efficacy of such treatment. Prompted by the finding of androgen receptor expression in salivary duct carcinoma, we sought to further explore the expression patterns, if any, of another nuclear hormone receptor, peroxisome proliferator-activated receptor $\gamma(\operatorname{PPAR} \gamma)$, in salivary duct carcinoma.

PPAR $\gamma$ is a member of the nuclear hormone receptor superfamily, which consists of a group of ligand-activated transcription factors that possess diverse biological functions $(7,8)$. The molecular structure of PPAR $\gamma$ shows a central DNA-binding domain, an amino-terminal activation domain (AF1), a carboxyl-terminal ligand-binding domain (LBD), and a ligand-dependent activation domain (AF-2) (9). PPAR $\gamma$ forms a heterodimeric DNAbinding complex with retinoid $\mathrm{X}$ receptor, and both (PPAR $\gamma$ and retinoid $X$ receptor) can be independently or coactivated by specific natural or synthetic ligands, leading to regulation of specific transcription genes $(9-12)$. The natural ligands for PPAR $\gamma$ that have been identified include the potent eicosanoid 15-deoxy- $\Delta^{12,14}$ prostaglandin $\mathrm{J}_{2}$ (15d-PG $\mathrm{J}_{2}$ ), and linoleic acid, whereas synthetic ones include thiazolidinediones such as troglitazone, rosiglitazone, and pioglitazone. The thiazolidinedione ligands are currently used as oral insulin sensitizers and antihyperglycemic drugs in patients with non-insulindependent diabetes mellitus (9, 13-15).

PPAR $\gamma$ is expressed in several tissues, including adipose tissue, where the gamma 2 isoform is preferentially expressed. In addition to the antidiabetic effect, ligand-activated PPAR $\gamma$ promotes adipogenesis and also regulates the monocyte-macrophage anti-inflammatory activity. Recent studies have also shown that PPAR $\gamma$ inhibits tumor cell proliferation and induces their terminal differentiation $(16,17)$. Expression of PPAR $\gamma$ has been demonstrated in several cancers, including colorectal, pancreas, breast, and prostate carcinoma (16-18). However, to our knowledge, no studies have been carried out to evaluate PPAR $\gamma$ expression in salivary duct carcinoma.

In this study, we investigated and demonstrated by immunohistochemical staining the expression of PPAR $\gamma$ in salivary duct carcinoma. The expression of PPAR $\gamma$ in salivary duct carcinoma may provide a therapeutic target, in a fashion similar to the treatment of hormone receptor-expressing tumors such as prostate carcinoma (anti-androgen) and breast carcinoma (anti-estrogen, tamoxifen).

\section{MATERIALS AND METHODS}

The surgical pathology files of the University of Arkansas for Medical Sciences and the University of Pittsburgh Medical Center were searched for cases of salivary duct carcinoma. Fifteen cases with available microscopic slides and suitable paraffinembedded tissue blocks were identified for the period 1990 and 2000. Tissue from the resection tumor specimens, including portions of normal salivary gland, were fixed in $10 \%$ neutral buffered formalin, routinely processed, embedded in paraffin, sectioned at $5 \mu \mathrm{m}$, and stained with hematoxylin and eosin. Fourteen patients were treated with parotidectomy with or without a neck dissection and/or radiation therapy. Only one patient was treated with radiation therapy alone. The clinical data and the histologic sections were reviewed to confirm the diagnosis.

Five-micrometer sections of formalin-fixed paraffin-embedded tissue were cut and prepared for IHC staining. The sections were incubated overnight at $4^{\circ} \mathrm{C}$ with a monoclonal antibody against human PPAR $\gamma$ (E-8; Santa Cruz Biotechnology, Santa Cruz, CA) at 1:50 dilution. A case of prostate carcinoma with known expression of PPAR $\gamma$ was used as positive control, whereas negative controls were generated by replacement of the primary antibody with a matched primary antibody of unrelated specificity. Before incubation with the primary antibody, all sections were subjected to antigen retrieval by the heat steam method and were endogenous peroxidase quenched with blocking solution (Zymed Laboratories, San Francisco, CA). The standard avidin-biotin-peroxidase technique was used using the Zymed Kit Detection system (Zymed Laboratories). The immunostaining was assessed semiquantitatively by two pathologists (PM and CYF), and the results were scored as follows: no staining being negative $(-)$; $\leq 20 \%$ positive cells being weakly negative $(+) ; 30$ to $40 \%$ positive cells being mildly positive $(++)$; 50 to $70 \%$ positive cells being moderately positive $(+++)$; and $>70 \%$ being intensely positive $(++++)$. For the purposes of this study, the expression of PPAR $\gamma$ is considered strong if the staining is scored as +++ or $++++;++$ and + represent moderate and weak expression, respectively; and \pm or - indicate negative expression.

\section{RESULTS}

The clinical data and immunohistochemical staining results are summarized in Table 1 . The tumors studied were from 10 men and 5 women, with an age range of 36 to 86 years (mean $=67.4 \mathrm{y}$ ). All of the 12 tumors arose from the parotid gland, and the majority of patients presented with Stage IV 
TABLE 1. Clinical Data, PPAR $\gamma$ Immunostaining Results, Treatment, and Patient Follow-Up in 15 Salivary Duct Carcinomas Cases

\begin{tabular}{|c|c|c|c|c|c|c|c|c|c|}
\hline $\begin{array}{c}\text { Case } \\
\#\end{array}$ & Age/Sex & $\begin{array}{l}\text { Tumor } \\
\text { Location }\end{array}$ & TNM/Stage & IHC & $\begin{array}{l}\text { Staining } \\
\text { Extent }\end{array}$ & $\begin{array}{l}\text { Parotidectomy/ } \\
\text { Neck Dissection }\end{array}$ & $\begin{array}{l}\text { Radiation } \\
\text { Therapy }\end{array}$ & $\begin{array}{l}\text { Recurrence/ } \\
\text { Metastasis }\end{array}$ & Follow-Up \\
\hline 1 & $57 / \mathrm{M}$ & Parotid & $\mathrm{T} 2 \mathrm{~N} 1 / \mathrm{IV}$ & +++ & Diffuse & Yes/Yes & Yes & No & Alive/ $12 \mathrm{~m}$ \\
\hline 2 & $61 / \mathrm{M}$ & Parotid & $\mathrm{T} 2 \mathrm{~N} 2 / \mathrm{IV}$ & ++++ & Diffuse & Yes/Yes & Yes & Local & Lost \\
\hline 3 & $66 / F$ & Parotid & T2N2/IV & +++ & Diffuse & Yes/Yes & Yes & No & Alive/13 m \\
\hline 4 & $58 / \mathrm{M}$ & Parotid & T3N0/II & $+1-$ & Focal & No/No & Yes & Local & Dead/12 m \\
\hline 5 & $68 / \mathrm{M}$ & Parotid & T3N2/IV & + & Focal & Yes/Yes & Yes & Unknown & Lost \\
\hline 6 & $84 / \mathrm{M}$ & Parotid & T2N0/IV & ++ & Diffuse & Yes/Yes & Yes & Yes & Alive $/ 30 \mathrm{~m}$ \\
\hline 7 & $67 / \mathrm{F}$ & Parotid & T1N0/I & ++ & Diffuse & Yes/Yes & Yes & No & Alive/34 m \\
\hline 8 & $37 / \mathrm{F}$ & Parotid & T1N0/I & $+1-$ & Focal & Yes/Yes & Yes & No & Alive/44 m \\
\hline 9 & $77 / \mathrm{M}$ & Parotid & T2N0/I & +++ & Diffuse & Yes/No & Yes & No & Alive $/ 24 \mathrm{~m}$ \\
\hline 10 & $36 / \mathrm{M}$ & Parotid & T4N0/IV & +++ & Diffuse & Yes/No & Yes & Local & Dead/10 m \\
\hline 11 & $78 / \mathrm{M}$ & Parotid & T4N2/IV & +++ & Diffuse & Yes/Yes & Yes & Distant & Dead/6 m \\
\hline 12 & $86 / \mathrm{F}$ & Parotid & T3N2/IV & +++ & Diffuse & Yes/Yes & Yes & Local & Dead/15 m \\
\hline 13 & $49 / \mathrm{F}$ & Parotid & T3N2/IV & +++ & Diffuse & Yes/Yes & Yes & No & Alive $/ 29 \mathrm{~m}$ \\
\hline 14 & $60 / \mathrm{M}$ & Parotid & TXN2/IV & +++ & Diffuse & Yes/Yes & Yes & Distant & Dead/13 m \\
\hline 15 & $66 / \mathrm{F}$ & Parotid & T4N0/IV & - & $\mathrm{N} / \mathrm{a}$ & Yes/Yes & Yes & Local & Lost \\
\hline
\end{tabular}

IHC, immunohistochemistry; TNM; tumor node metastases; N/a, not applicable.

disease. The duration of symptoms ranged from 2 to 9 months, and all patients presented with a neck mass around the parotid area. The masses were painless in all but three patients, in whom the pain was associated with recent enlargement. Other symptoms seen at presentation included VIIth nerve palsy (2 patients), vocal cord paralysis (1 patient), and cervical lymph node enlargement (7 patients). Radical parotidectomy was performed on 14 patients, but all patients received radiation treatment. At the time of radical resection of the tumors, 10 patients were found to have lymph node metastases and/or adjacent soft tissue involvement. Subsequent follow-up of the 15 patients for $\leq 44$ months (mean $=20.2 \mathrm{mo}$ ) has shown that 5 died of their disease within 6 to 13 months, whereas 7 are alive with no evidence of disease and 3 patients have been lost to follow-up.

\section{Pathologic Findings}

On gross inspection of the resected specimens, the majority (12 of $15,80 \%$ ) of the tumors exhibited poor circumscription and showed extension into adjacent soft tissue. Cystic degeneration, necrotic foci, and hemorrhage were also seen in many tumors.

Microscopically, the tumors displayed the typical features, which have been described in salivary duct carcinoma (Fig. 1A). The tumor growth pattern was characterized by infiltrating ductal and intraductal components, with the latter demonstrating a variety of patterns including solid, papillary, cystic, and cribriform (Fig. 1C). The infiltrating ductal component showed small nests, cords, and single tumor cells embedded in dense desmoplastic collagenous stroma. Angiolymphatic and perineural invasion by tumor was present in many cases. In addition, foci of calcification were also noted. The individual tumor cells were predominantly charac- terized by nuclear enlargement, with hyperchromasia, prominent nucleoli, variably increased nuclear to cytoplasmic ratios, abundant amphophilic or eosinophilic cytoplasm, and frequent mitoses.

\section{Immunohistochemical Detection of PPAR $\gamma$}

The immunohistochemical staining of salivary duct carcinoma showed positive diffuse staining for PPAR $\gamma$ in the majority of cases (12 of $15,80 \%$ ), with $75 \%$ (9 of 12) of the cases showing strong staining (Fig. 1B). Two (17\%) and 1 (8\%) of the cases demonstrated moderate and weak staining for PPAR $\gamma$. Only $3(20 \%)$ of total cases studied were negative for PPAR $\gamma$ expression (Fig. 1C). Of the positive cases, the staining pattern was uniform throughout the tissue section, with almost all neoplastic cells showing positive staining in the cytoplasm of most cases (with minimal or no nuclear staining). In two cases, the staining for PPAR $\gamma$ displayed a granular cytoplasmic pattern (Fig. 1C). Cytoplasmic staining of the PPARs has been described before (19). In addition, positive cytoplasmic staining in the striated and intercalated ducts of the normal salivary glands was also noted, whereas the acinar and stromal cells were negative, thus providing good internal control for the immunohistochemical staining (Fig. 2).

\section{Statistical Analysis}

Statistical analysis, in our small series of salivary duct carcinoma, showed no correlation between the level of PPAR $\gamma$ expression and tumor stage (TNM and clinical), recurrence, or patient survival.

\section{DISCUSSION}

The current main treatment modality for salivary duct carcinoma is complete surgical excision fol- 

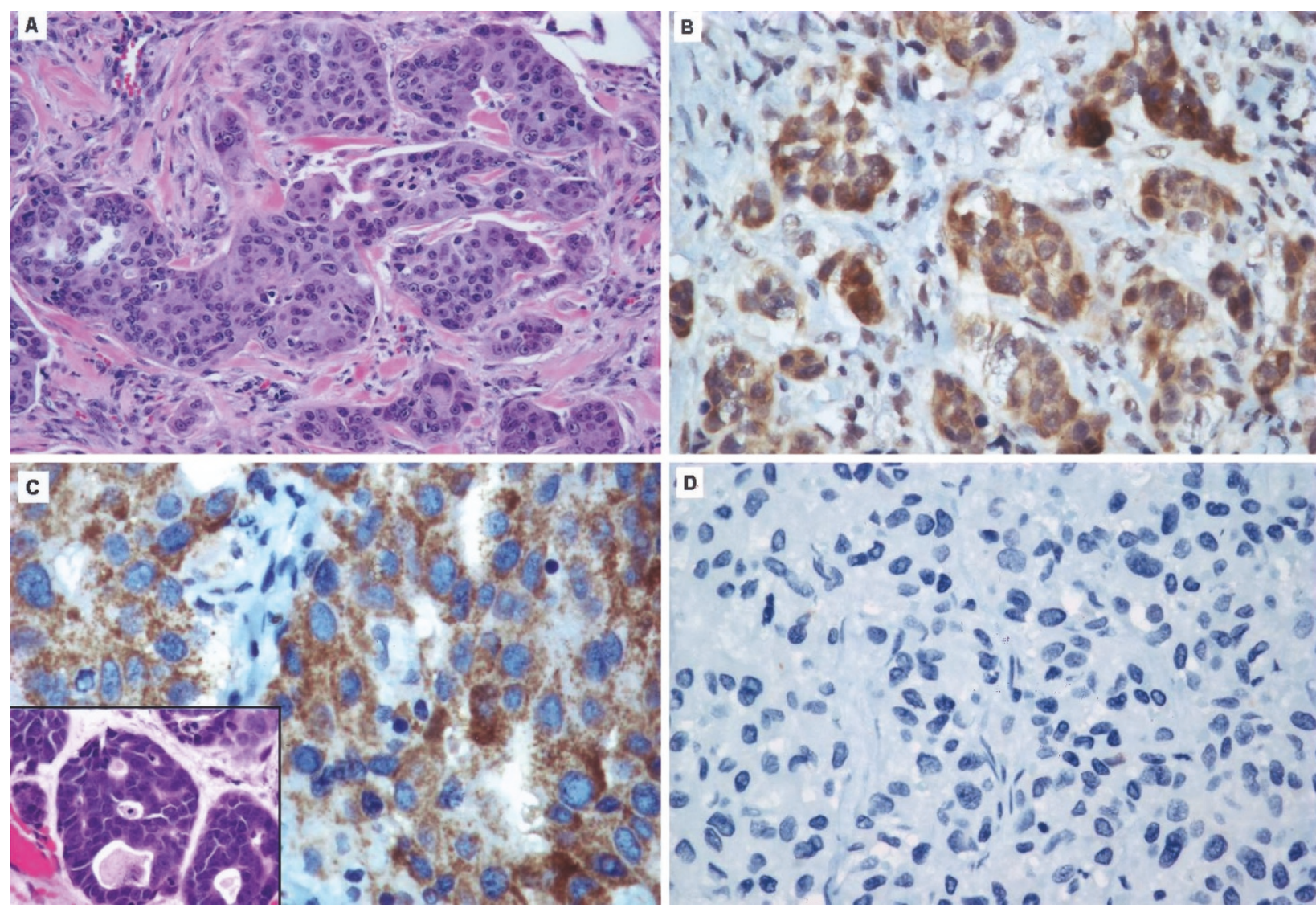

FIGURE 1. A, histologic sections of invasive salivary duct carcinoma showing tumor cells with atypical nuclei, prominent nucleoli, and abundant eosinophilic cytoplasm. B, immunoperoxidase staining for PPAR $\gamma$ in salivary duct carcinoma showing strong positive diffuse cytosolic expression. $\mathbf{C}$, tumor (glandular and cribriform pattern) displaying granular cytoplasmic staining (inset, hematoxylin-eosin section of tumor with cribriform pattern). D, one of three cases negative for PPAR $\gamma$ expression.

lowed by radiation therapy (4). However, salivary duct carcinoma frequently presents at an advanced stage (Stage IV for most patients in our study), therefore leading to treatment failure in most cases. Approximately $60 \%$ of the patients with salivary duct carcinoma die within 4 years of initial diagnosis $(3,4)$. Currently, there is no effective chemother-

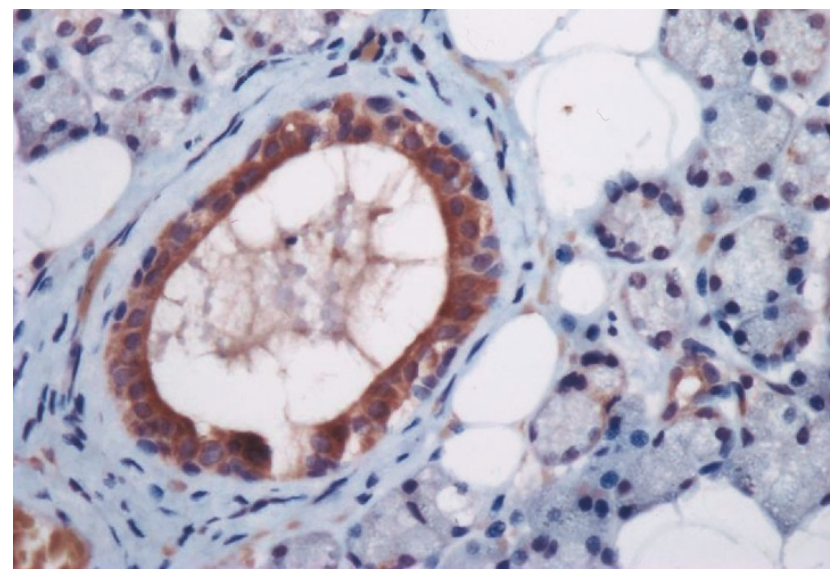

FIGURE 2. Normal salivary gland tissue; expression of PPAR $\gamma$ is present only in the ductal epithelium. Acinar cells and stromal tissue do not express PPAR $\gamma$. apy for this malignancy, thus making the management of patients with distant metastases difficult.

We observed in our study high levels of PPAR $\gamma$ expression in many salivary duct carcinoma, 12 of $15(80 \%)$, and that expression was predominantly limited to the cytoplasm. Our interest in investigating the expression of PPAR $\gamma$ in salivary duct carcinoma arose from the observation that salivary duct carcinoma express androgen receptor, which is also a nuclear hormone receptor $(4,5)$. In a previous study, androgen receptor expression was seen in $\leq 92 \%$ of salivary duct carcinoma, leading to speculation that hormonal treatment may have a role in the management of this tumor (4). Therapy targeted at hormone receptors has been successfully used in the treatment of prostate carcinoma (androgen ablation) and breast carcinoma (tamoxifen), both nuclear hormone receptor-expressing tumors. Salivary duct carcinoma shows some immunophenotypic similarity to prostate carcinoma, like prostate carcinoma and in addition to androgen receptor expression; it also expresses prostatespecific antigen and prostate acid phosphatase (20). Salivary duct carcinoma bears microscopic resemblance to breast carcinoma, which itself shows spo- 
radic androgen receptor expression; and it is therefore not surprising that investigators have looked for estrogen and progesterone receptor expression in salivary duct carcinoma. However, estrogen and progesterone receptor expression in salivary duct carcinoma appears to be infrequent $(5,6,21,22)$. Another notable finding was the demonstration of PPAR $\gamma$ expression in both prostate carcinoma and ductal carcinoma of the breast (23-25). The expression of PPAR $\gamma$ in salivary duct carcinoma suggests that it may be possible to specifically target this receptor in the treatment of patients with this tumor.

The antiproliferative effect of PPAR $\gamma$ is mediated through the inhibition of the cyclin D1 gene. Wang et al. (9) demonstrated that when PPAR $\gamma$ is activated by $15 \mathrm{~d}-\mathrm{PG} \mathrm{J}_{2}, \mathrm{PGD}_{2}$ or by the synthetic ligand troglitazone, the result was inhibition of cyclin D1, blocking entry of the cell cycle into the S phase. This effect was not observed in cells that were deficient of PPAR $\gamma$ (26). The antiproliferative effects of $\operatorname{PPAR} \gamma$ ligands have been observed in breast, colon, and recently, in pancreatic carcinoma $(18,27)$. In addition, PPAR $\gamma$ ligands also induce terminal differentiation in fibroblasts, human breast cancer, and liposarcoma cells. In the latter case, PPAR $\gamma$ ligands have been shown to arrest proliferation of liposarcoma cells and promote their maturation into adipocytes $(16,28,29)$.

A contradictory biologic effect was the observation in murine studies that troglitazone-activated PPAR $\gamma$ promoted tumorigenesis in the colon (27, $30-32)$. It is speculated that the apparent tumorigenic activity of PPAR $\gamma$ in the colon in these animals may be related to its anti-inflammatory effects, whereby a diminished inflammatory function may lead to a decrease in tumor surveillance $(9,31$, 33).

In our study, PPAR $\gamma$ expression was predominantly cytoplasmic. Shibuya et al. (34) demonstrated that nitration of PPAR $\gamma$ in macrophage cell lines (RAW 264), resulted in inhibition of the liganddependent translocation of PPAR $\gamma$ into the nucleus. Normally PPAR $\gamma$-ligand binding occurs in the cytosol, followed by translocation into the nucleus. Whether PPAR $\gamma$ in salivary duct carcinoma is nitrated or not or the translocation into the nucleus is precluded by a different mechanism remains unknown and requires further investigation.

Although PPAR $\gamma$ expression did not correlate with tumor stage, recurrence, or survival, its significance is that it provides a potential target site for therapeutic manipulation.

In summary, we have demonstrated a high level of expression of PPAR $\gamma$ in most salivary duct carcinoma. The diverse biologic functions of PPAR $\gamma$ and the mechanisms of specific ligand activation are complex and are yet to be fully understood. How- ever, the expression of PPAR $\gamma$ in salivary duct carcinoma and other tumors offers a potential therapeutic target for developing drugs that specifically bind and activate this receptor to alter tumor growth.

\section{REFERENCES}

1. Kleinsasser O, Klein HJ, Hubner G. Speichelgangcarcinoma. Ein den Milchgangcarcinoma der Brustdruse analoge Gruppe von Speildrusen tumoren. Arch Klin Exp Ohre Nasen Kehlkopfheikd 1968;192:100-5.

2. Seifert G, Sobin LH. Histological typing of salivary gland tumours. World Health Organization International histological classification of tumours. 2nd ed. New York: SpringerVerlag; 1991.

3. Barnes L, Rao U, Krause J, Contis L, Schwartz A, Scalamogna P. Salivary duct carcinoma. Part I: clinicopathologic evaluation and DNA image analysis of 13 cases with review of the literature. Oral Surg Oral Med Oral Pathol 1994;78:64-73.

4. Fan C-Y, Wang J, Barnes EL. Expression of androgen receptor and prostatic specific markers in salivary gland duct carcinoma. An immunohistochemical analysis of 13 cases and review of the literature. Am J Surg Pathol 2000;24:579-86.

5. Kapadia SB, Barnes L. Expression of androgen receptor, gross cystic disease fluid protein, and CD44 in salivary duct carcinoma. Mod Pathol 1998;11:1033-8.

6. Barnes L, Rao U, Krause J, Contis L, Schwartz A, Scalamogna P. Salivary duct carcinoma. Part II: immunohistochemical evaluation of 13 cases for estrogen and progesterone receptors, cathepsin D and c-erbB-2 protein. Oral Surg Oral Med Oral Pathol 1994;78:74-80.

7. Mangesdorf DJ, Thummel C, Beato M, Herrlich P, Schutz B, Umesono $\mathrm{K}$, et al. The nuclear receptor superfamily: the second decade. Cell 1995;83:835-9.

8. Lemberger T, Desvergne B, Wahli W. Peroxisome proliferator-activated receptors: a nuclear receptor signalling pathway in lipid physiology. Annu Rev Cell Dev Biol 1996;12:335-63.

9. Wang C, Fu M, D'Amico M, Albanese C, Zhou J-N, Brownlee $\mathrm{M}$, et al. Inhibition of cellular proliferation through $\mathrm{I} \kappa \mathrm{B}$ kinase-independent and peroxisome proliferator-activated receptor gamma-dependent repression of cyclin D1. Mol Cel Biol 2001;21:3057-70.

10. Mukherjee R, Jow L, Croston GE, Paterniti JRJ. Identification, characterization, and tissue distribution of human peroxisome proliferator-activated receptor (PPAR) isoforms PPAR $\gamma 2$ versus PPAR $\gamma 1$ and activation with retinoid X receptor agonists and antagoists. J Biol Chem 1997;272:8071-6.

11. Fajas L, Auboeuf D, Raspe E, Schoonjans K, Lefebvre AM, Saladin $\mathrm{R}$, et al. The organization, promoter analysis, and expression of the human PPAR $\gamma$ gene. J Biol Chem 1997;272: 18779-89.

12. Yang W, Rachez C, Freedman LP. Discrete roles of peroxisome proliferator-activated receptor $\gamma$ and retinoid $X$ receptor in recruiting nuclear receptor co-activators. Mol Cell Biol 2000;20:8008-17.

13. Lehmann JM, Moore LB, Smith-Oliver TA, Wilkinson WO, Willson TM, Kliewer SA. An antidiabetic thiazolidinedione is a high affinity ligand for peroxisome proliferator-activated receptor gamma (PPAR gamma). J Biol Chem 1995;270:12953-6.

14. Kliewer SA, Sundseth SS, Jones SA, Brown PJ, Wisely GB, Koble CS, et al. Fatty acids and eicosanoids regulate gene expression through direct interactions with peroxisome proliferator-activated receptor alpha and gamma. Proc Natl Acad Sci USA 94;94:4318-23.

15. Forman BM, Tontonoz P, Chen J, Brun RP, Spiegelman BM, Evans RM. 15-deoxy-delta 12, 14-prostaglandin J2 is a ligand 
for the adipocyte determination factor PPAR gamma. Cell 1995;83:803-12.

16. Tontonoz P, Singer S, Forman BM, Sarraf P, Fletcher JA, Fletcher CD, et al. Terminal differentiation of human liposarcoma cells induced by ligands for peroxisome proliferator-activated receptor $\gamma$ and the retinoid X receptor. Proc Natl Acad Sci U S A 1997;94:237-41.

17. Mueller E, Sarraf P, Tontonoz P, Evans RM, Martin KJ, Zhang $\mathrm{M}$, et al. Terminal differentiation of human breast cancer through PPAR $\gamma$. Mol Cell 1998;1:465-70.

18. Brockman JA, Gupta RA, Dubois RN. Activation of PPAR $\gamma$ leads to inhibition of anchorage-independent growth of colorectal cancer cells. Gastroenterology 1998;115:1049-55.

19. Akiyama TE, Baumann CT, Sakai S, Hager GL, Gonzalez FJ. Selective intranuclear redistribution of PPAR isoforms by RXR alpha. Mol Endocrinol 2002;16:707-21.

20. van Krieken JHJM. Prostate marker immunoreactivity in salivary gland neoplasms. A rare pitfall in immunohistochemistry. Am J Surg Pathol 1993;17:410-4.

21. James GK, Pudek M, Berean KW, Diamandis EP, Archibald DL. Salivary duct carcinoma secreting prostate-specific antigen. Am J Clin Pathol 1996;106:242-7.

22. Lewis JE, McKinney BC, Weiland LS, Ferreiro JA, Oslen KD. Salivary duct carcinoma: clinicopathologic and immunohistochemical review of 26 cases. Cancer 1996;77:223-30.

23. Smith MR, Kantoff PW. Peroxisome proliferator-activated receptor gamma (PPargamma) as a novel target for prostate cancer. Invest New Drugs 2002;20:195-200.

24. Segawa Y, Yoshimura R, Hase T, Nakatani T, Wada S, Kawahito Y, et al. Expression of peroxisome proliferator-activated receptor (PPAR) in human prostate cancer. Prostate 2002;51: 108-16.

25. Kubota T, Koshizuka K, Williamson EA, Asou H, Said JW, Holden S, et al. Ligand for peroxisome proliferator-activated receptor gamma (troglitazone) potent antitumor effect against human prostate cancer both in vitro and in vivo. Cancer Res 1998;58:3344-52.

26. Altiok S, Xu M, Spiegelman BM. PPARgamma induces cell cycle withdrawal: inhibition of E2F/DP DNA-binding activity via down-regulation of PP2A. Genes Dev 1998;11:1987-98.

27. Sarraf P, Mueller E, Jones D, King FJ, DeAngelo DJ, Patridge JB, et al. Differentiation and reversal of malignant changes in colon cancer through PPAR $\gamma$. Nat Med 1998;4:1046-52.

28. DuBois RN, Gupta R, Brockman JA, Reddy BS, Krakow SL, Lazar MA. The nuclear eicosanoid receptor, PPARgamma, is aberrantly expressed in colonic cancers. Carcinogenesis 1998;19:49-53.

29. Kliewer SA, Lenhard JM, Willson TM, Patel I, Morris DC, Lehmann JM. A prostaglandin J2 metabolite binds peroxisome proliferator-activated receptor $\gamma$ and promotes adipocyte differentiation. Cell 1995;83:813-9.

30. Lefebvre AM, Chen I, Desreumaux P, Najib J, Fruchart JC, Geboes $\mathrm{K}$, et al. Activation of the peroxisome proliferatoractivated receptor $\gamma$ promoted the development of colon tumors in C57BL/6J-APC ${ }^{\mathrm{Min}} /+$ mice. Nat Med 1998;4:1053-7.

31. Saez E, Tontonoz P, Nelson MC, Alvarez JG, Ming UT, Baird $\mathrm{SM}$, et al. Activators of nuclear receptor PPAR $\gamma$ enhance colon polyp formation. Nat Med 1998;4:1058-61.

32. Seed B. PPAR $\gamma$ and colorectal carinoma: conflicts in a nuclear family. Nat Med 1998;4:1004-5.

33. Rosen ED, Walkey CJ, Puigserver P, Spiegelman BM. Transcriptional regulation of adipogenesis. Genes Dev 2000;14: 1293-307.

34. Shibuya A, Wada K, Nakajima A, Saeki M, Katayama K, Mayumi T, et al. Nitration of PPAR $\gamma$ inhibits liganddependent translocation into the nucleus in a macrophagelike cell line, RAW 264. FEBS Lett 2002;525:43-7. 